\title{
Malaria in Jayapura District, Papua Province, Indonesia and resistance to sulfadoxine-pyrimethamine
}

\author{
Yohanna Sorontou ${ }^{1}$, Puji B.S Asih ${ }^{2}$, Septelia I. Wanandi ${ }^{3}$, Wahyuning Ramelan ${ }^{4}$, Din Syafruddin ${ }^{2,5}$
}

\begin{abstract}
Abstrak
Malaria merupakan masalah kesehatan utama di propinsi Papua. Meluasnya penyebaran parasit malaria dan penanganan program malaria yang tidak teratur serta diikuti adanya krisis ekonomi dan perselisihan di masyarakat Papua pada akhir tahun 1990an telah mengakibatkan situasi malaria di daerah Papua semakin terpuruk. Untuk menentukan besaran permasalahan malaria saat ini, suatu survei malariometrik telah dilakukan di tiga Kecamatan di Kabupaten Jayapura serta uji sensitifitas obat antimalaria sulfadoksin-pirimetamin (SP) pada pasien malaria di unit rawat jalan RSU Abepura, Puskesmas Hamadi dan Poliklinik Panti Asuhan Katolik Sentani, Kabupaten Jayapura, Propinsi Papua. Pada survei malariometrik, dari 543 subyek yang diperiksa, ditemukan 185 subyek terinfeksi malaria P.falciparum, dan P.vivax serta infeksi campuran keduanya. Seluruh kasus malaria yang ditemukan merupakan kasus tanpa gejala (asimtomatik). Pada uji sensitifitas obat antimalaria dengan SP, dari 56 subyek yang diikutsertakan, ditemukan 32 subyek mengalami kegagalan pengobatan dini (KPD) dan 2 subyek mengalami kegagalan pengobatan kasep (KPK) serta 22 subyek berhasil pada pengobatan ini. Hasil-hasil di atas menunjukkan bahwa prevalensi malaria di Kabupaten Jayapura serta angka kegagalan pengobatan SP cukup tinggi dan oleh karena itu diperlukan adanya obat antimalaria baru yang sesuai dengan keadaan pada daerah tersebut. (Med J Indones 2007; 16:32-8)
\end{abstract}

\begin{abstract}
Malaria poses a major public health problem in Papua. The rapid spread of drug-resistant parasites and deterioration of the malaria control program following the monetary crisis and civil strife in the late 90 'es have worsened the malaria situation in many areas of Papua. To re-assess the current magnitude of malaria problem, a malariometric survey was conducted in three sub-districts of Jayapura District, as well as antimalarial drug sensitivity test using sulfadoxine-pyrimethamine (SP) at the outpatient clinics of Abepura General Hospital (RSU), Hamadi Primary Health Center and Panti Asuhan Katolik Clinics, Sentani, Jayapura District, Papua Province. Screening of 543 subjects in three sub-districts revealed 185 malaria positive subjects, either with P. falciparum, $P$. vivax or mixed of the two species. All of the malaria cases were asymptomatic. In the SP drug sensitivity test, of the 56 subjects involved, 32 were classified as early treatment failure and two subjects were classified as late treatment failure. The remaining 22 subjects were classified as adequate clinical and parasitological response (ACPR). These results indicated that the surveyed area has a high malaria prevalence and treatment failure to SP and therefore alert to the need of deploying new antimalarial regiment that suit the remote setting. (Med J Indones 2007; 16:32-8)
\end{abstract}

Keywords: malaria, sulfadoxine-pyrimethamine (SP) resistance, Jayapura District, Indonesia

Malaria represents a major public health problem in Indonesia especially in eastern islands, including Papua province. In the year 2001, It was found that approx. 15 millions people were contracted with malaria,

\footnotetext{
${ }^{1}$ Biomedic Program, Faculty of Medicine, University of Indonesia

${ }^{2}$ Eijkman Institute for Molecular Biology, Jakarta, Indonesia

${ }^{3}$ Department of Biochemistry, Faculty of Medicine, University of Indonesia, Jakarta, Indonesia

${ }^{4}$ Department of Medical Biology, Faculty of Medicine, University of Indonesia

${ }^{5}$ Department of Parasitology, Faculty of Medicine, Hasanuddin University, Makasar, Indonesia
}

and thirty thousands death were reported. Studies performed within the last few years in various localities in Papua documented the malaria prevalence ranged from meso-to holoendemic status in the northeastern coast and highland parts of the province. ${ }^{1,2}$ This persistently high incidence of malaria in the area within the last few years was mainly attributed to the rapid spread of parasite resistance to the first and second line antimalarial drugs, chloroquine and sulfadoxine-pyrimethamine, and the lack of sustainable malaria control program. ${ }^{3-5}$ Resistance to chloroquine in Indonesia was first documented in Papua in $1975^{6,7}$ and current studies reported that this drug may no longer be effective in most areas of Papua. ${ }^{4}$ Resistance 
to the second line antimalarial drug, sulfadoxinepyrimethamine, was also first reported in Papua in $1985^{8}$ and continued to spread throughout the archipelago afterward.

The malaria treatment in this area follows the guidelines set by the Ministry of Health, ${ }^{5}$ whereby chloroquine ( $25 \mathrm{mg}$ base/kg body weight in three doses over 72 -hour period), followed by $15 \mathrm{mg}$ primaquine base per day for two weeks for $P$. vivax or a single $45 \mathrm{mg}$ dose for $P$. falciparum, was used as first line therapy. The sulfadoxine-pyrimethamine combination is usually used as a second line therapy. The continued use of the two antimalarial drugs in this area despite its growing resistance status was associated with the lack of therapeutic options in the setting of a frontier area, where most treatment were given without proper monitoring and merely based on clinical symptom only. The aim of the present study was to determine the magnitude of the malaria problem in Jayapura district as well as the extent of the parasite resistance to antimalarial drug, sulfadoxine-pyrimethamine. Here we report the prevalence of malaria and the rate of treatment failure associated with the sulfadoxinepyrimethamine treatment in the area.

\section{METHODS}

Description of Study sites. The location of the Jayapura District within the Papua Province of Indonesia is shown in Figure 1. Jayapura District is located in the northeastern part of Papua Province, has an area of $17,514 \mathrm{~km} 2$ and population of approx. $110,786 .{ }^{9}$ The district is bordered in the north by Pacific Ocean, in the south by Jayawijaya district, in the west with Yawa and Paniai district, and in the east with the Papua New Guinea. The Jayapura district is administratively divided into 24 sub-districts. The district is geographically consisting of marshy land and highland and rivers. The climate is typically tropical with average temperature between $25-35^{\circ} \mathrm{C}$. The dry and wet seasons is not distinctly separated, with drier season between May to November and the monsoon between December to April. The average population of each village was approx. 2,000 people. The population consisted mainly of Papuan ethnic group, migrants from Java and Sulawesi. The majority of the population work as farmer or fisherman.

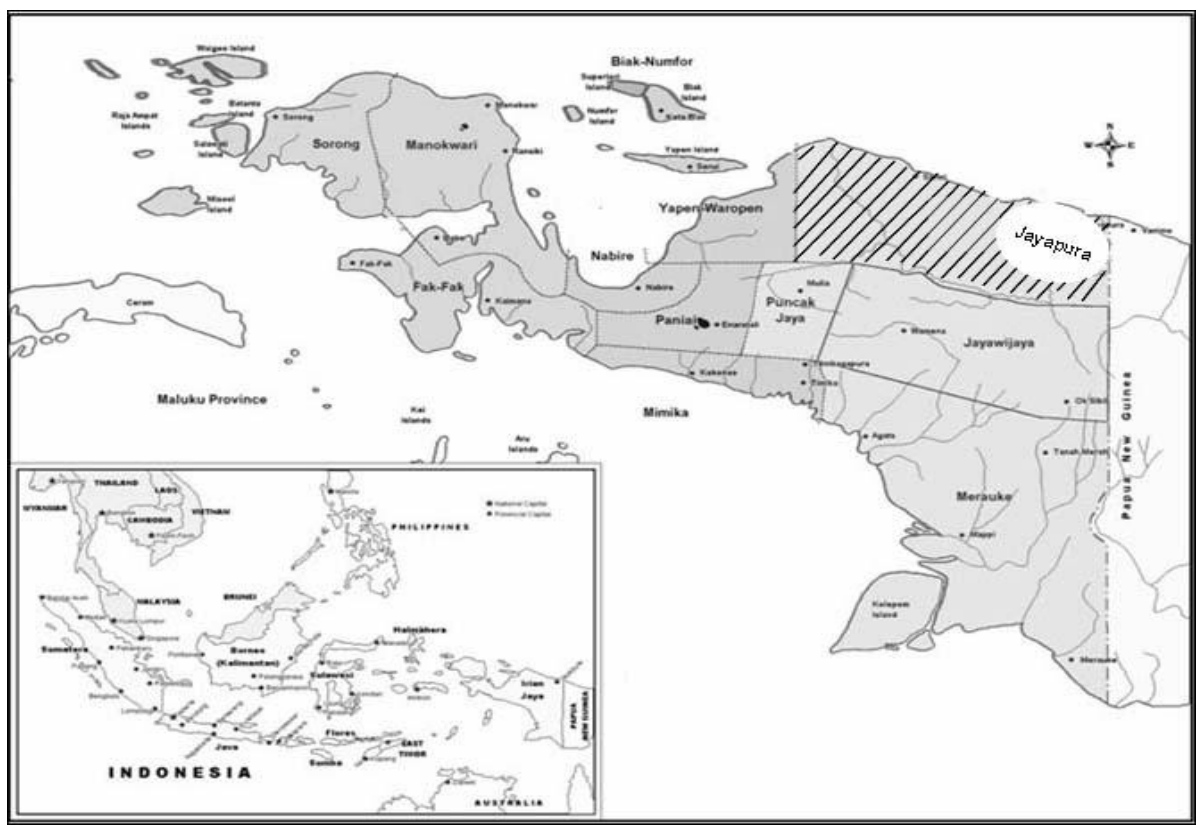

Figure 1. A sketch map of the Jayapura District (lined area), Jayapura City (white circle) and its geographic location within the Indonesia archipelago (inset). 
Sample collection. A malariometric survey was conducted during 18-28 January 2005 in two selected villages in each of the three sub-districts, Jayapura Utara, Depapre and Sentani. The selected villages represented the coastal and inland environmental setting of malaria. The target population was the village inhabitants who joined voluntarily, and the blood will be taken through finger prick and prepared for thick and thin blood smear or blots on filter paper (3MM; Whatman, Hillsboro, OR). During the survey, basic 7-day morbidity history including axial temperature, antimalarial drug use and drug allergy were checked. This study was carried out with the approval by the Ethics Committees at the Faculty of Medicine, University of Indonesia, Jakarta, Indonesia.

Parasite detection. Thick and thin blood smears taken during the malariometric survey were stained with Giemsa, and subsequently examined by light microscopy. Parasite density was determined by counting the number of parasites per leukocytes in 100-highpower microscopic fields in a Giemsa-stained thick film, assuming an average of 20 leukocytes per microscopic field and 8000 leukocytes $/ \mu 1$ of blood. Slides were declared negative if parasite could not be detected in 100 microscopic fields. The parasite count was classified as: $(+)$ if 1-10 parasites were found per 100 thick film fields, $(++)$ if $11-100$ parasite per 100 microscopic thick film fields, $(+++)$ if 1-10 parasite per one thick film fields and (++++) if more than 10 parasites per one thick film fields. ${ }^{10}$
Antimalarial drug sensitivity test. The antimalarial drug sensitivity test with sulfadoxine-pyrimethamine was conducted during 9 July-28 September 2005 by recruiting malaria infected individuals in the outpatient clinics of RSU Abepura, Puskesmas Hamadi and Poliklinik Panti Asuhan Katolik Sentani, Jayapura District, Papua Province. The criteria for patients' inclusion in the test include: age between 1-65 year old, patients do not have any symptom and sign of cerebral complication, mono infection with falciparum, parasite density of $>1000$ parasite $/ \mu \mathrm{l}$ blood, and signed the informed consent. ${ }^{11}$ A standard SP regiment was given to the subject based on the bodyweight and age under the observation of a nurse, and following the guidelines recommended by the Ministry of Health.

\section{RESULTS}

\section{Malariometric surveys}

Among the 543 subjects involved in the survey in 5 villages, of Jayapura Utara, Depapre and Sentani subdistricts, $185(34.1 \%)$ subjects were found to be positive for malaria, consisting $120(22.1 \%)$ subjects carried $P$. falciparum, $58(10.7 \%)$ subjects carried $P$. vivax and $7(1.3 \%)$ subjects carried both $P$. falciparum and $P$. vivax (Table 1). The highest slide positivity rate was found in Tablasupa village of Depapre subdistrict. Except in Sentani villages, P. falciparum was found to be the dominant species.

Table 1. Malaria prevalence in Jayapura District

\begin{tabular}{|c|c|c|c|c|c|c|}
\hline \multirow[t]{2}{*}{ District } & \multirow[t]{2}{*}{ Village } & \multirow{2}{*}{$\begin{array}{c}\text { Malaria } \\
\text { Cases }\end{array}$} & \multicolumn{3}{|c|}{ Species } & \multirow{2}{*}{$\begin{array}{c}\sum \\
\text { Positive }\end{array}$} \\
\hline & & & Pf & $\mathbf{P v}$ & $\mathbf{P f}+\mathbf{P v}$ & \\
\hline \multirow{2}{*}{ Jayapura Utara } & Hamadi Pantai & 148 & $40(27 *)$ & $6(4.05)$ & $2(1.35)$ & 45 (30.4) \\
\hline & Hamadi Lembah & 89 & $8(9)$ & $4(4.5)$ & $1(1.1)$ & $12(13.5)$ \\
\hline Depapre & $\begin{array}{l}\text { Depapre, } \\
\text { Tablasupa I dan II }\end{array}$ & 96 & $43(45)$ & $17(17.7)$ & $2(2.1)$ & $57(59.4)$ \\
\hline \multirow{2}{*}{ Sentani } & Danau Sentani & 65 & $10(15.4)$ & $25(38.5)$ & $1(1.5)$ & $36(55.4)$ \\
\hline & Sereh Atas & 145 & $19(13.1)$ & $6(4.1)$ & $1(0.7)$ & $25(17.2)$ \\
\hline Total & & 543 & $120(22.1)$ & $58(10.7)$ & $7(1.3)$ & $185(34.1)$ \\
\hline
\end{tabular}

(*) Number in bracket indicates percentage, $\mathrm{Pf}=$ Plasmodium falciparum, $\mathrm{Pv}=$ Plasmodium vivax 
Based on the age group, the majority of the falciparum and vivax malaria cases occurred at younger age (Table 2). Falciparum malaria cases where slightly higher in men, whereas vivax cases were found to be almost doubled in women. Subjects that carried mixed infection was also predominantly found in men and at younger age.

The parasite density and the presence of malaria symptom such as fever, chill, headache in malaria cases and nausea is shown in Table 3. Based on the parasitic density, the majority of the cases $(82.7 \%)$ carried low parasitemia whereas the remaining carried mild and high parasitemia (Table 3). Twenty nine of the malaria cases, 21 falciparum malaria and 8 vivax malaria, were found to have symptom ranging from fever, chill, headache and nausea. The majority of the subjects that carry malaria symptom in falciparum malaria, was from the group that harbor low parasitemia whereas in vivax malaria, the subjects having malaria symptom are found in all parasite density levels. In falciparum malaria cases, the proportion of cases carrying gametocyte is also relatively high (43.3\%, data not shown).

\section{Antimalarial drug sensitivity test}

At the outpatient's clinics, a total 100 symptomatic falciparum malaria cases were found. The clinical manifestation among the subjects varied greatly from mild fever, anemia, splenomegaly, chill, head ache, nausea, lost of conscience and coma. Majority of the cases were from the age group of over 20 years old, and the remaining were from age group of 10-20 and less than 10 . Of these, only 56 cases met the criteria to be involved in the antimalarial drug sensitivity test using sulfadoxine-pyrimethamine. The remaining 44 cases were classified as severe malaria and received standard antimalarial drug treatment in the hospital. Of the 56 subjects that were involved in the drug test, 32 cases exhibited no significant reduction in parasitemia at days 3 and therefore were classified as early treatment failures. Two other subjects were found to be positive at days 14 and classified as late treatment failure. The remaining 22 subjects were found to recover completely and were classified as adequate clinical and parasitological response (ACPR) (Table 4).

Table 2. Malaria prevalence by age group, sex and species in Jayapura District

\begin{tabular}{|c|c|c|c|c|c|c|c|}
\hline \multirow{3}{*}{$\begin{array}{c}\text { Age } \\
\text { (year) }\end{array}$} & \multicolumn{6}{|c|}{ Malaria Cases } & \multirow{3}{*}{ Total } \\
\hline & \multicolumn{2}{|c|}{$\mathrm{Pf}$} & \multicolumn{2}{|c|}{$\mathrm{Pv}$} & \multicolumn{2}{|c|}{$\mathrm{Pf}+\mathrm{Pv}$} & \\
\hline & $\mathrm{M}$ & $\mathrm{F}$ & M & $\mathrm{F}$ & $\mathrm{M}$ & $\mathrm{F}$ & \\
\hline $0<-10$ & $31(37 *)$ & $21(25)$ & $15(18)$ & $14(16)$ & $3(3)$ & $1(1)$ & 85 \\
\hline $10-20$ & $14(22.2)$ & $21(33.3)$ & $9(14.3)$ & $! 7(27)$ & $2(3.2)$ & 0 & 63 \\
\hline$>20$ & $12(32)$ & $11(30)$ & 0 & $14(38)$ & 0 & 0 & 37 \\
\hline Total & 57 & 53 & 24 & 45 & 5 & 1 & 185 \\
\hline
\end{tabular}

(*) Number in bracket indicates percentage, Pf:Plasmodium falciparum,

Pv: Plasmodium vivax; M, Male; F, Female

Table 3. Parasite density and the presence of malaria symptom among malaria cases in Jayapura District

\begin{tabular}{|c|c|c|c|c|c|c|}
\hline \multirow{2}{*}{$\begin{array}{l}\text { Parasite density } \\
\text { (per } \mu \mathrm{L})\end{array}$} & \multirow[t]{2}{*}{ Pf } & \multirow[t]{2}{*}{$\mathrm{Pv}$} & \multirow[t]{2}{*}{$\mathrm{Pf}+\mathrm{Pv}$} & \multirow[t]{2}{*}{ Total } & \multicolumn{2}{|c|}{ Malaria Symptom } \\
\hline & & & & & $\mathrm{Pf}$ & $\mathrm{Pv}$ \\
\hline $40-400 \quad(+1)$ & $100(65.3 *)$ & $47(20.7)$ & $6(4)$ & 153 & 19 & 3 \\
\hline $401-4000(+2)$ & $9(52.9)$ & $8(47.1)$ & 0 & 17 & 1 & 1 \\
\hline $4001-39.999(+3)$ & $4(57.1)$ & $3(42.9)$ & 0 & 7 & 0 & 3 \\
\hline$\geq 40.000(+4)$ & $7(87.5)$ & $1(12.5)$ & 0 & 8 & 1 & 1 \\
\hline Total & 120 & 59 & 6 & 185 & 21 & 8 \\
\hline
\end{tabular}

(*) Number in bracket indicates percentage, Pf:Plasmodium falciparum, Pv: Plasmodium vivax; M, Male; F, Female 
Table 4. Treatment monitoring and outcome of the subjects enrolled in in-vivo drug sensitivity test in Abepura General Hospital, Hamadi Primary Health Centre, and Panti Asuhan Katolik Clinics, Sentani, Jayapura District, Papua Province.

\begin{tabular}{|c|c|c|c|c|c|c|c|c|c|c|}
\hline \multirow{2}{*}{$\begin{array}{c}\text { Sample } \\
\text { Code }\end{array}$} & \multicolumn{7}{|c|}{ Parasitemia } & \multicolumn{3}{|c|}{ Results } \\
\hline & $\mathrm{HO}$ & $\mathrm{H} 2$ & $\mathrm{H} 3$ & $\mathrm{H} 7$ & $\mathrm{H} 14$ & $\mathrm{H} 21$ & $\mathrm{H} 28$ & ETF & LTF & ACPR \\
\hline 1-KPA & + & + & - & - & - & - & - & & & 1 \\
\hline 2-KPA & + & + & - & - & + & - & - & & 1 & \\
\hline 3-KPA & + & + & + & + & + & - & - & 1 & & \\
\hline 4-KPA & + & + & + & + & + & - & - & 1 & & \\
\hline 5-KPA & + & + & + & + & + & + & - & 1 & & \\
\hline 6-KPA & + & - & - & + & + & - & - & & 1 & \\
\hline 7-KPA & + & + & + & + & - & - & - & 1 & & \\
\hline 8-KPA & + & + & + & + & - & - & - & 1 & & \\
\hline 9-KPA & + & + & - & - & - & - & - & & & 1 \\
\hline $10-\mathrm{KPA}$ & + & + & - & - & - & - & - & & & 1 \\
\hline 11-KPA & + & + & + & - & - & - & - & 1 & & \\
\hline 12-KPA & + & + & + & + & - & - & - & 1 & & \\
\hline 13-KPA & + & - & - & - & - & - & - & & & 1 \\
\hline 14-KPA & + & + & + & - & - & - & - & 1 & & \\
\hline 15-KPA & + & + & + & - & - & - & - & 1 & & \\
\hline 16-KPA & + & + & + & + & - & - & - & 1 & & \\
\hline 17-KPA & + & + & + & + & - & - & - & 1 & & \\
\hline 18-PDA & + & - & - & - & - & - & - & & & 1 \\
\hline 19-PDA & + & + & + & + & + & + & - & 1 & & \\
\hline 20-PDA & + & + & + & - & $*$ & & & 1 & & \\
\hline 21-PDA & + & + & + & - & $*$ & & & 1 & & \\
\hline 22-PDA & + & + & + & - & $*$ & & & 1 & & \\
\hline 23-PDA & + & + & + & $*$ & & & & 1 & & \\
\hline 24-PDA & + & + & - & $*$ & & & & & & 1 \\
\hline 25-PDA & + & + & + & - & $*$ & & & 1 & & \\
\hline 26-PDA & + & + & + & - & $*$ & & & 1 & & \\
\hline 27-PDA & + & + & + & + & - & $*$ & & 1 & & \\
\hline 28-PDA & + & + & + & - & $*$ & & & 1 & & \\
\hline 29-PDA & + & + & - & $*$ & & & & & & 1 \\
\hline 30-PDA & + & + & + & - & $*$ & & & 1 & & \\
\hline 31-PDA & + & + & + & - & $*$ & & & 1 & & \\
\hline 32-PDA & + & + & + & - & $*$ & & & 1 & & \\
\hline 33-PDA & + & + & + & - & $*$ & & & 1 & & \\
\hline 34-PDA & + & + & - & - & $*$ & & & & & 1 \\
\hline 35-PDA & + & - & - & $*$ & & & & & & 1 \\
\hline 36-PDA & + & - & - & - & $*$ & & & & & 1 \\
\hline 37-PDA & + & + & + & + & - & $*$ & & 1 & & \\
\hline 38-PDA & + & - & - & - & $*$ & & & & & 1 \\
\hline 39-PDA & + & + & - & $*$ & & & & & & 1 \\
\hline 40-PDA & + & - & - & $*$ & & & & & & 1 \\
\hline 41-PDA & + & - & - & $*$ & & & & & & 1 \\
\hline 42-PDA & + & - & - & $*$ & & & & & & 1 \\
\hline 43-PDA & + & + & + & + & $*$ & & & 1 & & \\
\hline 44-PDA & + & + & + & $*$ & & & & 1 & & \\
\hline 45-PDA & + & + & + & - & $*$ & & & 1 & & \\
\hline 46-PKH & + & + & + & - & $*$ & & & 1 & & \\
\hline 47-PKH & + & + & + & $*$ & & & & 1 & & \\
\hline 48-PKH & + & + & + & - & $*$ & & & 1 & & \\
\hline 49-PKH & + & - & - & $*$ & & & & & & 1 \\
\hline $50-\mathrm{PKH}$ & + & + & + & - & $*$ & & & 1 & & \\
\hline 51-PKH & + & - & - & $*$ & & & & & & 1 \\
\hline 52-PKH & + & - & - & $*$ & & & & & & 1 \\
\hline 53-PKH & + & - & - & $*$ & & & & & & 1 \\
\hline 54-PKH & + & - & - & $*$ & & & & & & 1 \\
\hline 55-PKH & + & - & - & $*$ & & & & & & 1 \\
\hline 56-PKH & + & - & - & $*$ & & & & & & 1 \\
\hline Total & & & & & & & & 32 & 2 & 22 \\
\hline
\end{tabular}

ETF: Early Treatment Failure; LTF: Late Treatment Failure; ACPR: Adequate Clinical and Parasitological Response; *: LTFU (Lost to follow up) 


\section{DISCUSSION}

The malariometric survey indicated that all selected villages have a meso - to high endemic status. Areas with mesoendemic status include coastal Hamadi whereas Depapre, Tablasupa I and II, of the Depapre sub-district had high endemic status. In all villages, two species of the malaria parasites, $P$. falciparum and $P$. vivax were found either as a single infection or mixed of the two species. This malaria situation, although only indicated the point prevalence and probably does not really reflect the annual parasite incidence in the area, is relatively similar to that reported previously in various sites in Papua. $5,12,13$

Based on the age group, nearly half of the malaria cases were from the age group of less than 10 year old. Of these, 20 subjects had age ranged from 0-4 years. The mixed infection cases were also mainly found in this age group. The findings are in accordance with the common phenomenon in many malaria endemic regions where the younger age group is most vulnerable and also indicated that malaria transmission occurred in all selected villages. Malaria infection in infant and young children is generally associated with local transmission as they mostly stay at home and have not frequently traveled as that the elder age. The high proportion of falciparum malaria cases carrying gametocytes also indicated a high potential transmission in the surveyed area. This phenomenon was also recently seen in our study in West Sumba. ${ }^{14}$

The malariometric survey also revealed that the majority of the 185 malaria positive subjects exhibited no symptom and sign for malaria and microscopic analyses showed that $82.7 \%$ of the total cases had a low parasite density. The findings indicated that the majority of the subjects may have acquired naturally immunity to enable them develop malaria without or subtle clinical manifestation and that are most likely to have long been exposed to malaria. Previous studies that follow non-immune Javanese migrants to Papua indicated that susceptibility to parasitemia and fever in adults showed an age dependent diminution after 2 years and this phenomenon is parallel to the lifelong resident in the area. ${ }^{15}$

The high treatment failure rate with the antimalarial drug, sulfadoxine-pyrimethamine, in the area indicated an alarming situation for the use of this drug. Sulfadoxine-pyrimethamine have been more widely used in the last few years in Indonesia following the spread of chloroquine resistance. ${ }^{16}$ Although its use should consider certain condition such as allergy to sulpha drugs, the formulation of this drug is preferred as it is simple and being given in a single dose, and therefore very much fit to the condition in Papua and frontier sites in Indonesia where access to the health facilities are very much limited. The $60.7 \%$ failure rate that was found in this study is a three-fold increase to that results reported previously. ${ }^{17}$ This significant increase in treatment failure was probably associated with the massive use of this drug following the failure of chloroquine to treat most malaria cases in this area. In support of the findings, molecular analyses of various blood samples from the area indicated that the $P$. falciparum isolates collected from this areas have indeed carried the drug-resistant alleles for both chloroquine and sulphadoxine-pyrimethamine. ${ }^{5,16}$ In this regard, to fill the lack of suitable antimalarial treatment regiment in this area, a new antimalarial drug combination such as artemisinin-based combination therapy (ACT) is highly recommended to be deployed.

In conclusion, our malariometric survey and antimalarial drug test using sulphadoxine-pyrimethamine in Jayapura District revealed a high malaria point prevalence in the area as well as a high treatment failure rate with the drug. These results alert to the need of deploying new antimalarial regiment that suit the remote setting where the malaria diagnosis and treatment were mainly based on clinical symptom and without proper monitoring.

\section{Acknowledgements}

We thank Staff at the Departments of Biochemistry and Parasitology Faculty of Medicine, University of Indonesia for the technical assistance, Officials at the Provincial and District Health Departments, Technical staff at Public Heath Center in Hamadi, General Hospital, Jayapura for their support and assistance in the field work. This study is a part of the dissertation of YS that was submitted as a partial fulfillment to obtain a $\mathrm{Ph} . \mathrm{D}$ degree at the Biomedics program, Faculty of Medicine, University of Indonesia.

Financial support: This study received financial support partially from the Papua Provincial Government through Beasiswa-Pemda Papua.

\section{REFERENCES}

1. Bangs MJ, Soelarto T, Barodji, Wicaksana BP, Boewono DT. Colonization of Anopheles maculatus from Central 
Java, Indonesia. J Am Mosq Control Assoc. 2002;18(4): 359-63.

2. Nagesha HS, Syafruddin D, Casey GJ, Susanti AI, Fryhauff DJ, Reeder JC et al. Mutations in the pfmdr-1, dhfr and dhps genes of Plasmodium falciparum are associated with in vivo drug resistence in Irian Jaya, Indonesia. Trans R Soc Trop Med Hyg. 2001; 95:43-9.

3. Taylor WR, Widjaja H, Richie TL, Basri H, Ohrt C, Tjitra, et al. Chloroquine/Doxycyc- line combination versus chloroquine alone, and doxycycline alone for the treatment of Plasmodium falciparum and Plasmodium vivax malaria in northeastern Irian Jaya, Indonesia. Am J Trop Med Hyg. 2001; 64(5-6):223-8.

4. Sumawinata I, Bernadeta, Leksana B, Sutamihardja A, Purnomo, Subianto B et al. Very high risk of therapeutic failure with chloroquine for uncomplicated $\mathrm{P}$. falciparum and P. vivax malaria in Indonesia-Papua. Am J Trop Med Hyg. 2003; 68(4):416 - 20.

5. Syafruddin D, Asih PBS, Siregar JE, and Tjitra E. Molecular basis of antimalarial drug resistance in Indonesia. Adv Exp Med Biol. 2003; 531:103-15.

6. Ebisawa I, Fukuyama T. Chloroquine - resistant falciparum malaria from West Irian and East Kalimantan. Ann Trop Med Parasitol. 1975; 69:131-2.

7. Ebisawa I, Fukuyama T. Chloroquine-resistance of Plasmodium falciparum in West Irian and East Kalimantan. Ann Trop med Parasitol 1975b: 69:275-82.

8. Hoffman SL, Rustama D, Dimpudus AJ, Punjabi NH, Campbell JR, Oetomo HS et al. R II and RIII type resistance of Plasmodium falciparum to combination of mefloquine and sulfadoxine/pyrimethamine in Indonesia. Lancet 2. 1985;1038-40.

9. United Nation Development Program (UNDP). Kajian Kebutuhan Papua. UNDP; 2005.

10. Gilles HM. Diagnostic method in malaria. Golles HM, Warrel DA, eds. In: Bruce-Chwatt's Essential malariology.
New York, NY: Oxford University Press; 1993.p.79-95.

11. World Health Organization. Assessment and monitoring of antimalarial drug efficacy for the treatment of uncomplicated falciparum malaria. Geneva: WHO; 2003.

12. Tjitra E, Supriyanto S, Currie BJ, Morris PS, Saunders JR, Anstey NM. Therapy of uncomplicated falciparum malaria: A randomized trial comparing artesunate plus sulfadoxinepyrimethamine versus sulfadoxine-pyrimethamine alone in Irian Jaya, Indonesia. Am J Trop Med Hyg. 2001;65 (4):309-17.

13. Baird JK, Wiady I, Fryauff DJ, Sutamihardja MA, Leksana B, et al. In vivo resistance to chloroquine by Plasmodium vivax and Plasmodium falciparum at Nabire, Irian Jaya, Indonesia. Am J Trop Med Hyg. 1997; 56(6):627-31.

14. Syafruddin D, Puji BS Asih, Farah N Coutrier, Leily T, Rintis N, Yaveth M et al. Malaria in Wanokaka and Loli Sub-district, West Sumba District, East Nusa Tenggara Province, Indonesia. Am J Trop Med Hyg. 2006; 74(5):733-7.

15. Keenihan SH, Gramzinski R, Sutanti R, Hilda H, Wiwi R, Soebianto $\mathrm{S}$ et al. Mechanism of innate and acquired protein against Plasmodium falciparum in Javanese transmigrant adult and children newly resident in malaria endemic Northwest Papua. Trop Dis. 2003:83-102.

16. Syafruddin D, Puji B.S. Asih, Gerard Casey, Jason Maquire, J.Kevin Baird, Hadya S. Nagesha et al. Molecular epidemiology of Plasmodium falciparum resistance to antimalarial drugs in Indonesia. Am J Trop Med Hyg. 2005; 72(2):174-81.

17. Tjitra E, Suprianto S, Anstey NM. Higer gametocyte prevalence following failure of treatment of Plasmodium falciparum malaria with sulfadoxine-pyrimethamine: Implication for progression of antifolate resistance. Trans R Soc Trop Med Hyg. 2002; 96(4):434-7. 